\title{
ANALISA DAMPAK KEBIJAKAN ATAS KENAIKAN IURAN JAMINAN KESEHATAN NASIONAL (STUDI DI KECAMATAN BULUKERTO)
}

\author{
Arief Budiono', Dita Ajeng Yulianie'2, Ferry Irawan Febriansyah'3 ${ }^{3}$, Rika \\ Maya Sari ${ }^{4}$, Dewi Iriani ${ }^{5}$, Nuryani ${ }^{6}$ \\ 1Universitas Muhammadiyah Surakarta \\ Corresponding Authors Email: Ab368@ums.ac.id \\ 2,3,4Universitas Muhammadiyah Ponorogo \\ 5IAIN Ponorogo \\ 6Poltekkes Kemenkes Prodi Kebidanan Magetan
}

Received: August 6, 2020, Accepted: Dec, 2020 /Published: April 30, 2021

DOI: https://doi.org/10.31764/jmk.v12i1.2722

\begin{abstract}
The urgency of this research is to analyze the impact of the increase in BPJS Health contributions to be used as a reference so that if there is a policy to increase the BPJS, Kesehatan no longer impacts society. Evaluating something that happens to be a lesson is of great urgency for legal research, especially in the context of policies related to BPJS Kesehatan. The research methodology is a juridical-empirical research method, using a qualitative descriptive approach. Data collection techniques, through interviews and distributing google forms. The study results show that the increase and increase in BPJS dues that occurred since January 1, 2020, impact the fees or the amount of money that a person must pay against the bill that appears; if not paid, then a fine will appear. The results of the google form questionnaire show that basically and in essence, policies related to BPJS Kesehatan are constructive for the community, which clearly proves legal welfare in the Bulukerto District area. This is evidenced by data from research respondents, that $97 \%$ of respondents actually appreciate the government programs related to BPJS Kesehatan positively. However, the policy that is written or the content of the BPJS Health policy being questioned by the community is the policy or regulation on the increase in BPJS contributions. The 28 respondents also evidence this on Google Form; 23 respondents have an objection to the policy.
\end{abstract}

Keywords: Indonesia; Health; BPJS.

\begin{abstract}
ABSTRAK
Urgensi dari penelitian ini adalah menganalisa dampak kenaikan iuran BPJS Kesehatan untuk dijadikan acuan agar jika terjadi kebijakan kenaikan BPJS Kesehatan lagi tidak berdampak kembali terhadap masyarakat. Mengevaluasi sesuatu yang terjadi menjadi sebuah pembelajaran merupakan urgensi besar sebuah penelitian hukum khususnya dalam
\end{abstract}


konteks kebijakan terkait BPJS Kesehatan. Metodologi penelitian dengan jenis penelitian yuridis-empiris, menggunakan pendekatan kualitatif yang bersifat deskriptif. Teknik pengumpulan data, melalui wawancara dan penyebaran google form. Hasil penelitian bahwa, Kenaikan dan melonjaknya iuran BPJS yang terjadi sejak tanggal 1 Januari 2020 yang lalu, berdampak pada iuran atau jumlah uang yang harus dibayar oleh seseorang terhadap tagihan yang muncul, jika tidak dibayar maka akan muncul dendanya. Hasil kuisoner google form, bahwa pada dasar dan hakikatnya, kebijakan terkait BPJS Kesehatan sangatlah membantu masyarakat dan itu sangat jelas membuktikan sebuah kesejahteraan hukum di wilayah Kecamatan Bulukerto. Hal itu dibuktikan berdasarkan data responden penelitian, bahwa 97\% responden sebenarnya mengapresiasi positif program pemerintah terkait dengan BPJS Kesehatan. Akan tetapi, kebijakan yang tertuliskan atau isi dari kebijakan BPJS Kesehatan yang dipermasalahkan masyarakat yaitu kebijakan atau aturan kenaikan iuran BPJS. Hal ini juga dibuktikan dengan dari 28 responden Google Form, 23 responden berpendapat keberatan dengan kebijakan tersebut.

Kata Kunci: Indonesia; Kesehatan; BPJS.

\section{PENDAHULUAN}

Di Indonesia sendiri terdapat suatu penyelenggara Sistem Jaminan Sosial seperti yang terdapat dalam UUD 1945 pasal $28 \mathrm{H}$ yang menyatakan bahwa setiap warga Indonesia berhak mendapatkan hidup sejahtera lahir dan batin, memiliki tempat tinggal dan memperoleh lingkungan hidup yang baik, berhak mendapatkan pelayanan kesehatan dan berhak atas jaminan sosial. ${ }^{1}$

Tingkat kebutuhan kesehatan nasional mengalami masalah ketika tidak disertai dengan adanya peningkatan pelayanan kesehatan dan disertai dengan tetapan kebijakan yang tidak disetujui rakyat. ${ }^{2}$

Sejarah jaminan sosial Indonesia sudah ada sejak dahulu yaitu pada masa penjajahan kolonial Belanda. Tahun 1949 setelah Indonesia telah diakui kedaulatannya oleh pemerintahan Belanda, usaha serta upaya agar

\footnotetext{
1 Pasal 28 H Undang Undang Dasar Negara Republik Indonesia Tahun 1945

2 Desi Hanggono Rarasati, “Dampak Kenaikan Tarif Bpjs Kesehatan Terhadap Pelayanan Kesehatan Di Kota Malang," Jurnal Politik Muda (2017).
} 
terealisasi jaminan layanan kesehatan masyarakat, teruntuk Pegawai Negeri Sipil dan keluarganya masih berlanjut. Menteri kesehatan Prof. G.A. Siwabessy ketika menjabat telah mengajukan pendapat yakni agar pemerintah segera menyelenggarakan program asuransi kesehatan yang waktu itu sudah mulai dilaksanakan di berbagai negara maju.

Tahun 1949 tersebut kepesertaannya ialah Pegawai Negeri Sipil. Di tahun 1968, pemerintah telah melahirkan Peraturan Menteri Kesehatan Nomor 1 Tahun1968 dan membentuk Badan Penyelenggara Dana Pemeliharaan Kesehatan (BPDPK) yang berugas untuk mengatur perawatan kesehatan pegawai negeri dan penerima pensiunan.

Tahun 1992, PHB beralih nama menjadi PT Akses (Persero) yaitu melewati Peraturan Pemerintah Nomor 6 tahun 1992. PT Aksese (Persero) menjangka karyawan BUMN dengan aturan yang baru yakni Akses Komersial. Januari tahun 2005, PT Askes (Persero) dipercayai pemerintah untuk menjalankan tugas jaminan kesehatan untuk warga yang miskin (PJKMM) yang diketahui sebagai program Askeskin iurannya dibayar oleh pemerintah. ${ }^{3}$

Terwujudnya Sistem Jaminan Sosial di Indonesia, maka dibentuklah Badan Penyelenggara Jaminan Sosial (BPJS) yang resmi bertugas serta berjalan sejak tahun 2014. Hal tersebut bermula ketika pemerintah menerbitkan Undang-Undang Nomor 40 tahun 2004 tentang Sistem Jaminan Sosial, pada saat itu PT Akses (Persero) yang ditugaskan dan sekarang dikenal sebagai BPJS Kesehatan. Warga Negara Indonesia (WNI) wajib mendaftarkan diri sebagai peserta BPJS. Warga Negara Asing (WNA) yang telah bekerja di wilayah Indonesia yang minimal masa kerjanya 6 bula maka wajib mendaftarkan diri sebagai peserta BPJS

\footnotetext{
${ }^{3}$ Eti Dewi Mutiara Subari, Henni Djuhaeni, and Guswan Wiwaha, “Analisis Faktor-Faktor Yang Memengaruhi Intensi Menjadi Peserta Mandiri Jaminan Kesehatan Pada Masyarakat Kota Cirebon," Universitas Padjadjaran (2014).
} 
Ketenagakerjaan ini sesuai dengan isi pasal 14 UU BPJS. Setiap perusahaan swasta wajib mendaftarkan karyawan atau pekerjanya sebagai anggota BPJS aktif.

Badan Penyelenggara Jaminan Sosial merupakan Badan Hukum Publik yang tugas dan tanggung jawabnya kepada presiden dan memiliki fungsi untuk menyelenggarakan jaminan kesehatan nasional bagi seluruh warga negara Indonesia, yaitu Pegawai Negeri Sipil, Penerima Pensiun PNS dan TNI/POLRI, Veteran, Perintis Kemerdekaan beserta anggota keluarganya, Badan Usaha, peserta mandiri yaitu rakyat sipil. ${ }^{4}$

BPJS Kesehatan juga merangap fungsi sebagai pemerintahan (governing function) di bidang pelayanan publik (public service) yang sebelumnya ditugaskan pada Badan Usaha Milik Negara dan sebigian pada lembaga pemerintahan. Rangkapan antara kedua fungsi itu yang menjadi status BPJS Kesehatan sebagai badan hukum publik yang menjalankan pelayanan publik.

Seiring berjalannya waktu, peraturan terkait BPJS Kesehatan juga berubah yakni Peraturan Presiden Nomor 64 Tahun 2020 Tentang Perubahan Kedua Atas Peraturan Presiden Nomor 82 Tahun 2018 Tentang Jaminan Kesehatan. Hukum dan aturan di Indonesia menganut asas Lex Posteori Derogat Lex Priori yaitu aturan yang lebih baru mengesampingkan aturan yang lebih lama, maka dari itu sekarang aturan BPJS Kesehatan menggunakan aturan yang lebih baru yang sudah ditetapkan oleh pemerintah beserta presiden. Kita sebagai warga negara wajib untuk mentaati aturan yang telah ada. ${ }^{5}$

Pelaksanaan Jaminan Kesehatan Nasional oleh BPJS meliputi seluruh wilayah Indonesia termasuk kecamatan Bulukerto, untuk menentukan

\footnotetext{
4 Mundiharno, "Peta Jalan Menuju Universal Coverage Jaminan Kesehatan (Road Map to a Universal Health Coverage)," Jurnal Legislasi Indonesia (2012).

${ }^{5}$ Murti, B., 2000. Dasar Dasar Asuransi Kesehatan. Penerbit Kansius, Yogyakarta.
} 
hasil riset dalam penelitian ini dimana di wilayah kecamatan Bulukerto, ada beberapa hal yang harus diketahui dulu sebelum dapat menganalilis data dan fakta dilapangan. Hal demikian ini dimaksudkan agar dalam analisa penelitian ini memiliki acuan dasar untuk menyimpulkan hasil penelitian ini.

BPJS Kesehatan merupakan sebuah program pemerintah yang sangat penting bagi masyarakat Indonesia khususnya kecamatan Bulukerto. Adanya BPJS Kesehatan sangat membantu dalam upaya menangani masalah kesehatan di wilayah kecamatan Bulukerto. Kesehatan merupakan kebutuhan yang cukup penting bagi masyarakat di sebuah negara.

Awal tahun 2020, dunia sedang dilanda wabah pandemi yaitu virus corona atau Covid-19 dimana virus ini menyebabkan negara negara di dunia kesulitan untuk memeranginya. Virus ini merupakan virus yang baru dan belum ditemukan vaksin hingga saat ini. Virus corona menyerang manusia melalui sistem perpanapasan. Efek dari adanya pandemi virus corona ini adalah sejumlah negara melakukan lockdown wilayah, masyarakat dibatasi kegiatannya seperti work from home, elearning, physycal distancing. Sejumlah pasar tradisional hingga supermarket ditutup, hal ini menyebabkan perekonomian dunia menjadi krisis akibat tidak adanya perputaran uang.

Pandemi Covid-19 ini malah pemerintah membuat kejutan yaitu menaikkan iuran BPJS Kesehatan. Padahal sebelumnya, 31 Maret 2020, Mahkamah Agung (MA) telah membatalkan kenaikan iuran yang ditetapkan melalui Perpres Nomor 75 Tahun 2019. Jika tidak dibatalkan lagi, kenaikan tarif BPJS Kesehatan akan berlaku mulai 1 Juli 2020. Walau belum ada pengajuan untuk judicial review, kenaikan iuran BPJS Kesehatan itu telah menimbulkan pro-kontra. Argumentasi yang disampaikan, untuk mendukung maupun menolak tarif baru iuran yang ditetapkan melalui 
Perpres No. 64 tahun 2020 tersebut beragam. Polemik yang terjadi dan sebagian besar marak di media sosial, dengan isu yang melebar telah menimbulkan keresahan yang dikhawatirkan dapat membuat arus masuk iuran dari peserta mandiri menurun.

Bermula dari adanya perubahan peraturan kenaikan iuran premi inilah yang menuntut pihak-pihak penyelenggara maupun penyedia pelayanan kesehatan untuk mampu memberikan pelayanan kesehatan yang aman, bermutu dan terjangkau. Sayangnya, usaha pemerintah dalam mewujudkan kesejahteraan masyarakat khususnya dibidang kesehatan tidak seimbang dengan adanya pembenahan sumber daya manusia dan fasilitas medis yang mendukung, oleh sebab itu masyarakat merasa dirugikan. $^{6}$

Urgensi dari penelitian ini tidak lain adalah menganalisa dampak kenaikan iuran BPJS Kesehatan untuk dijadikan acuan agar jika terjadi kebijakan kenaikan BPJS Kesehatan lagi tidak berdampak kembali terhadap masyarakat. Mengevaluasi sesuatu yang terjadi menjadi sebuah pembelajaran merupakan urgensi besar sebuah penelitian hukum khususnya dalam konteks kebijakan terkait BPJS Kesehatan. Pandemi Covid-19 memang bencana bagi berbagai sektor di Indonesia salah satunya adalah sektor kesehatan dan ekonomi di Indonesia.

Sebuah kebijakan yang membuat masyarakat justru menolak, terbebani dan sengsara, secara otomatis itu bukanlah kebijakan atau hukum yang adil dan memberikan manfaat bagi masyarakat. Artinya tujuan hukum sangat jelas tidak tercipta dalam kebi jakan kenaikan iuran BPJS Kesehatan.

Penelitian ini menarik untuk diteliti karena di kecamatan Bulukerto terjadi masalah kesejahteraan dan bertentangan dengan hukum terkait

\footnotetext{
${ }^{6}$ Rarasati, “Dampak Kenaikan Tarif BPJS Kesehatan Terhadap Pelayanan Kesehatan Di Kota Malang."
} 
tujuan hukum sendiri, yakni keadilan hukum, kepastian hukum, serta manfaat hukum itu sendiri. Dengan fokus permasalahan terhadap dampak yang ditimbulkan setelah kenaikan iuran Jaminan Kesehatan Nasional, dan keberlanjutan kepesertaan BPJS Kesehatan.

\section{METODOLOGI}

Jenis penelitian yang digunakan adalah metode yuridis-empiris dengan menggunakan pendekatan kualitatif yang bersifat deskriptif. Menggunakan metode wawancara mendalam (indepht interview). Penelitian ini dilakukan ditengah wabah pandemi Covid-19 yang menyerang diberbagai negara di dunia, namun penelitian tetap dilakukan dengan memperhatikan protokol kesehatan yakni tetap jaga jarak dengan responden dan memakai masker ketika wawancara. Penelitian ini terfokus di kecamatan Bulukerto yang sampelnya hanya mengambil 25 responden.

\section{PEMBAHASAN}

\section{A. Dasar Normatif dan Dampak yang ditimbulkan Setelah Kenaikan}

\section{Iuran Jaminan Kesehatan Nasional}

Peraturan adalah pijakan atau tata cara yang digunakan untuk membatasi dan menjembatani tingkah laku, perbuatan seseorang dalam suatu lingkup organisasi tertentu maupun lingkungan masyarakat agar mentaati sebuah peraturan, norma yang berlaku dan jika melanggar akan dikenai sanksi. Sanksi dapat berupa teguran, hukuman pidana, serta hukum sosial.

Indonesia memuat segala peraturan-peraturan yang tertulis dan dibukukan dalam Undang-Undang Dasar 1945 dimana dalam sebuah pasal-pasal terdapat aturan dan sanksi yang berbeda-beda. Seorang manusia perlu diatur karena manusia adalah makhluk sosial yang saling membutuhkan maka dari itu perlu hubungan yang harmonis antar 
makhluk sosial diperlukan batasan-batasan dalam berinteraksi dan bergaul. Dapat disimpulkan bahwa UUD 1945 menjadi tolok ukur peraturan di Indonesia.

Analisis adalah observasi terhadap masalah atau objek tertentu yang tujuannya adalah untuk mengetahui fakta dan keadaan aslinya, untuk mengetahui sebab-akibat suatu perkara atau peristiwa. Tujuan akhirnya adalah untuk mengurai suatu pokok permasalahan yang telah terjadi.

Dampak atau pengaruh adalah suatu ukuran yang merajuk pada pengaruh sosial, ekonomi, budaya dan lingkungan dalam suatu kegiatan tertentu. Dampak ini bisa dirasakan atau dinilai dalam jangka waktu yang sudah dilalui, maka setelah itu baru dapat disimpulkan dampak apa yang didapatkan setelah peristiwa yang terjadi atau dampak apa yang didapat dalam suatu kegiatan.

Kenaikan dalam hal ini berarti melonjaknya iuran BPJS yang telah terjadi dari tanggal 1 Januari 2020 yang lalu. Sedangkan iuran berarti jumlah uang yang harus dibayar oleh seseorang terhadap tagihan yang muncul, jika tidak dibayar maka akan muncul dendanya. Badan Penyelenggara Jaminan Sosial merupakan Badan Hukum Publik yang tugas dan tanggung jawabnya kepada presiden dan memiliki fungsi untuk menyelenggarakan jaminan kesehatan nasional bagi seluruh Warga Negara Indonesia, yaitu Pegawai Negeri Sipil, Penerima Pensiun PNS dan TNI/POLRI, Veteran, Perintis Kemerdekaan beserta anggota keluarganya, Badan Usaha, serta peserta mandiri yaitu rakyat sipil.

BPJS Kesehatan dilahirkan agar mampu memberikan jaminan sosial secara nasional untuk memenuhi kebutuhan dasar yang layak untuk seluruh masyarakat atas dasar asas kemanusiaan, manfaat dan keadilan. BPJS Kesehatan adalah sebuah lembaga yang memberikan pelayanan asuransi kesehatan dengan menggunakan sistem premi asuransi. Sistem 
premi asuransi disetiap pesertanya diwajibkan untuk membayar iuran sesuai kelas yang dipilih. ${ }^{7}$

BPJS Kesehatan juga merangkap fungsi sebagai pemerintahan (governing function) di bidang pelayanan publik (public service) yang sebelumnya ditugaskan oleh Badan Usaha Milik Negara dan sebigian oleh lembaga pemerintahan. Rangkapan antara kedua fungsi itu yang menjadi status BPJS Kesehatan sebagai badan hukum publik yang menjalankan pelayanan publik. ${ }^{8}$ UU Nomor 24 tahun 2011 tentang Badan Penyelenggara Jaminan Sosial menyatakan bahwa BPJS Kesehatan adalah badan hukum yang didirikan untuk menyelenggarakan jaminan sosial atau jaminan kesehatan. UU Nomor 40 tahun 2004 tentang Sistem Jaminan Sosial Nasional dalam pasal 5 ayat 1 dan pasal 52 menyatakan bahwa pembentukan Badan Penyelenggara Jaminan Sosial dan perubahan atas kelembagaan PT Askes (Persero), PT Jamsostek (Persero), PT TASPEN (Persero), dan PT ASABRI (Persero) menjadi Badan Penyelenggara Jaminan Sosial. Perubahan tersebut diikuti adanya pengalihan peserta, program, aset serta hak dan kewajibannya. Peraturan dalam undangundang ini membentuk BPJS menjadi 2 yaitu BPJS Kesehatan dan BPJS Ketenagakerjaan. BPJS Ketenagakerjaan meliputi program kecelakaan kerja, jaminan hari tua, jaminan pensiun, dan jaminan kesehatan. Sementara BPJS Kesehatan menyelenggarakan jaminan kesehatan. Dengan dibentuknya kedua macam BPJS tersebut jangkauan kepesertaan menjadi diperluas. Pelaksanaan BPJS Kesehatan dilakukan sesuai dengan UU SJSN pasal 19 ayat 1, jaminan kesehatan akan diselenggarakan secara nasional berdasarkan pada asuransi sosial dan prinsip ekuitas. ${ }^{9}$ Prinsip asuransi sosial adalah sebagai berikut :

\footnotetext{
7 Ibid, Rarasati, Desi. 2017. kesehatan.pdf

http://www.kemkes.go.id/resources/download/jkn/himpunan-peraturan-jaminan-

9 Undang-undang Nomor 24 Tahun 2011 Tentang Badan Penyelenggara Jaminan Sosial.
} 
a. Gotong royong antar orang kaya dan orang miskin, orang sakit dengan orang yang sehat, orang tua dengan yang muda, dan yang beresiko tinngi dan rendah

b. Kepesertaan bersifat wajib dan tidak memilah milih

c. Iuran berdasarkan persentase penghasilan

d. Bersifat nirlaba ${ }^{10}$

Prinsip ekuitas adalah kesamaan dalam memperoleh pelayanan sesuai dengan kebutuhan medis dan tidak terikat pada besaran iuran yang telah dibayarkan. ${ }^{11}$ Kepesertaan BPJS Kesehatan menurut Perpres RI No. 12 tahun 2013, peserta BPJS Kesehatan adalah setiap orang yaitu Warga Negara Indonesia, termasuk Warga Negara Asing yang bekerja paling singkat 6 (enam) bulan di Indonesia.

Kesejahteraan dalam istilah umumnya berarti merujuk pada keadaan yang membaik, keadaan yang damai dan tentram. Dalam kebijakan publik, kesejahteraan berarti pada keterjangkauan layanan untuk memberi kebutuhan masyarakat yang diberikan oleh pemerintah. Penyelenggaraan kesejahteraan sosial sangat diperlukan agar warga negara dapat memenuhi kehidupan yang layak dan sejahtera sehingga dapat menjalankan sebagai makhluk yang sosial. Dalam hal penyelenggaran kesejateraan ini diperlukan peran masyarakat, lembaga sosial serta pemerintah agar terjuwud kesejahteraan sosial yang terarah dan berkesinambungan.

Hukum merupakan seperangkat peraturan baik tertulis maupun tidak tertulis yang berisi norma-norma yang bertujuan untuk mengatur, mengendalikan perilaku warga negara dalam sebuah negara, menjaga ketertiban dan keadilan dan jika sebuah aturan tersebut dilanggar maka akan dikenai sanksi. Negara yang sejahtera juga memuat kesejahteraan hukum didalam program pemerintahannya, karena para warga negaranya

\footnotetext{
10 Pasal 4 Undang-undang Nomor 40 Tahun 2004 Tentang Sistem Jaminan Sosial Nasional.

11 Pasal 19 Undang-undang Nomor 40 Tahun 2004 Tentang Sistem Jaminan Sosial Nasional.
} 
telah dijamin hak-hak dan kewajibannya. Oleh karena itu, maka pemerintah selaku aparatur negara maka sudah semestinya menjamin warga negaranya yang berfungsi untuk menjalankan negara yang adil dan makmur ini sesuai dengan cita-cita UUD tahun 1945.

\section{B. Pelaksanaan dan Keberlanjutan Kepesertaan BPJS Kesehatan di Kecamatan Bulukerto}

Kecamatan Bulukerto merupakan daerah yang masuk ke wilayah kabupaten Wonogiri. Daerah ini terkenal dengan area dengan hawa atau suasana yang dingin. Kecamatan yang terletak di wilayah provinsi Jawa Tengah ini merupakan daerah berdekatan dengan perbatasan dengan kabupaten Ponorogo atau perbatasan provinsi Jawa Timur dengan provinsi Jawa Tengah. Kecamatan ini berjarak sekitar $43 \mathrm{~km}$ dari ibukota kabupaten Wonogiri ke arah timur. Pusat pemerintahannya berada di Desa Bulurejo. Pada tahun 2002, Kecamatan ini dimekarkan menjadi dua kecamatan yaitu kecamatan Bulukerto dan kecamatan Puhpelem. ${ }^{12}$

Di wilayah kecamatan Bulukerto terdapat 9 desa dan 1 kelurahan yang terbagi atas batasan batasan wilayah tertentu. Kabupaten Wonogiri merupakan kabupaten yang terletak di provinsi Jawa Tengah dengan jumlah penduduk 954.706 jiwa (BPS Kabupaten Wonogiri tahun 2017) dengan jumlah presentase penduduk berumur 15 tahun ke atas yang bekerja menurut lapangan pekerjaan utama yaitu total 516.294 jiwa yang mana hanya 45.310 jiwa yang bekerja di bidang industri. Kabupaten Wonogiri memiliki berbagai komoditi industri pengolahan yang tersebar di 25 kecamatan yang salah satu industri terdapat di Kecamatan Bulukerto. Kecamatan Bulukerto sendiri merupakan kecamatan yang lokasinya berada di timur dari Kabupaten Wonogiri yang berbatasan dengan Provinsi Jawa Timur. Dengan luas daerah 4.125,32 hektar.

\footnotetext{
12 https://id.wikipedia.org/wiki/Bulukerto, Wonogiri
} 
Kecamatan Bulukerto memiliki kepadatan penduduk sebanyak 29.332 jiwa ${ }^{13}$. Daerah ini merupakan daerah yang terkenal dengan industri terompetnya selain sektor pertanian.

Situasi sekarang berbeda dengan situasi dahulu, pandemi covid-19 menyebabkan kegiatan industri diwilayah ini bisa dikatakan lumpuh atau tidak bisa memperoduksi lagi dan ini berimbas pada perekonomian masyarakat. Hal ini juga berimbas pada pengguna BPJS Kesehatan. Dikeluarkannya aturan baru terkait kenaikan iuran BPJS membuat masyarakat yang memiliki kartu BPJS ini semakin sulit. Kebijakan pemerintah ini dinilai justru semakin memperburuk keadaan yang ada pada saat ini. Dengan keadaan jumlah penduduk 29.332 jiwa tentunya banyak pengguna BPJS yang terdampak akibat kebijakan ini. Hal ini jelas berdampak pada kesejahteraan masyarakat. Efektifitas hukum pun serasa diragukan karena justru menimbulkan efek yang merugikan masyarakat khususnya di wilayah kecamatan Bulukerto. Sebelum membaca data sektor kesehatan di wilayah ini, perlu dianalisa terlebih dahulu data sektor kesehatan di wilayah nasional.

Gambar 1.

Data Fasilitas Kesehatan Nasional.

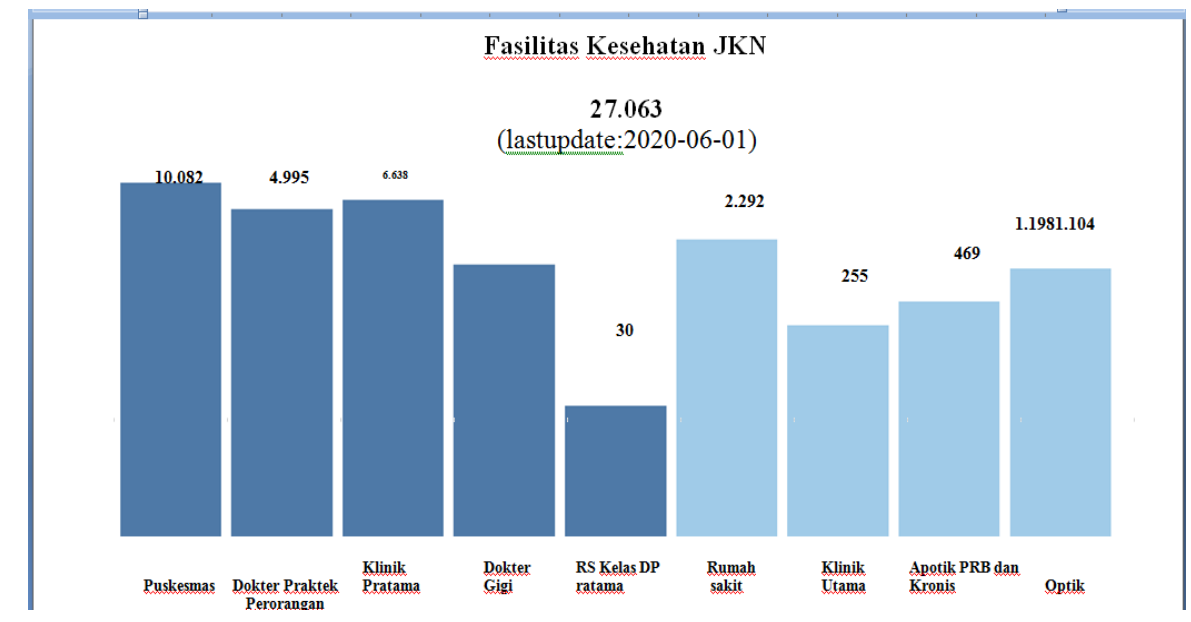

Sumber data: BPS Kabupaten Wonogiri 2017

\footnotetext{
13 Badan Pusat Statistik Kabupaten, Wonogiri Tahun 2017.
} 
Jika kita membaca data secara nasional, jumlah Rumah Sakit kelas D Pratama dan Rumah Sakit Umum di Indonesia lebih sedikit dibandingkan dengan jumlah fasilitas kesehatan lainnya, umumnya penggunaan BPJS Kesehatan adalah di wilayah Rumah Sakit, sehingga penentuan kebijakan menaikkan iuran BPJS jika dilihat dari data bisa dibilang tidak logis dan dapat merugikan masyarakat. Dikatakan demikian karena jika dalam skala nasional saja grafiknya demikian, secara otomatis alasan-alasan pemerintah menaikkan iuran BPJS cenderung tidak efektif.

Kesejahteraan tersebut harus dapat dinikmati secara berkelanjutan, adil, dan merata menjangkau seluruh rakyat. Dinamika pembangunan bangsa Indonesia telah menumbuhkan tantangan berikut tuntutan penanganan berbagai persoalan yang belum terpecahkan. Salah satunya adalah tentang penyelenggaraan sistem jaminan sosial bagi seluruh rakyat Indonesia sebagaimana yang diamanatkan dalam Pasal $28 \mathrm{H}$ ayat (3) "Setiap orang berhak atas jaminan sosial yang memungkinkan pengembangan dirinya secara utuh sebagai manusia yang bermartabat" dan Pasal 34 ayat (2) Undang-Undang Dasar Negara Republik Indonesia tahun 1945 yang berbunyi “Negara mengembangkan sistem jaminan sosial bagi seluruh rakyat dan memberdayakan masyarakat lemah dan tidak mampu sesuai harkat martabat kemanusiaan".$^{14}$

Pelaksanaan UU BPJS melibatkan PT ASKES, PT ASABRI, PT JAMSOSTEK dan PT TASPEN. Dimana PT ASKES dan PT JAMSOSTEK beralih dari Perseroan menjadi Badan Publik mulai 1 januari 2014. Sedangkan PT ASABRI dan PT TASPEN pada tahun 2009 beralih menjadi badan publik dengan bergabung ke dalam BPJS ketenagakerjaan.

\footnotetext{
${ }_{14}$ Irawati Indrianingrum and Indah Puspitasari, "EVALUASI PROSES SISTEM RUJUKAN BADAN PENYELENGGARA JAMINAN KESEHATAN SOSIAL (BPJS) KESEHATAN DI FASILITAS KESEHATAN TINGKAT PERTAMA (FKTP) KABUPATEN JEPARA," Jurnal Ilmu Keperawatan dan Kebidanan (2021).
} 
Pembentukan badan publik yaitu BPJS merupakan sebuah kebijakan. ${ }^{15}$ Bahwa kebijakan publik itu bentuk awalnya adalah penetapan tindakan pemerintah.

a. Bahwa kebijakan publik tersebut tidak cukup dinyatakan dalam bentuk teks-teks formal belaka namun juga harus dilaksanakan atau diimplementasikan secara nyata.

b. Bahwa kebijakan publik tersebut pada hakekatnya harus mempunyai tujuan-tujuan dan dampak-dampak, baik jangka pendek maupun jangka panjang yang telah di pikirkan secara matang terlebih dulu.

c. Dan pada akhirnya seluruh proses yang ada diatas di peruntukkan bagi pemenuhan kepentingan masyarakat. ${ }^{16}$

Setelah mengetahui beberapa riset data kesehatan nasional, kemudian akan dipelajari tentang data-data yang ada di kecamatan Bulukerto. Seperti yang sudah dibahas sebelumnya. Jumlah penduduk Kecamatan Bulukerto sekarang ini setelah melakukan riset 36.170 jiwa, dan sekitar 19.000 jiwa menggunakan fasilitas BPJS Kesehatan baik peserta mandiri maupun PBI. Berikut adalah persebaran penduduk kecamatan Bulukerto pada tiap desa :

Gambar 2. Data Penduduk Kecamatan Bulukerto

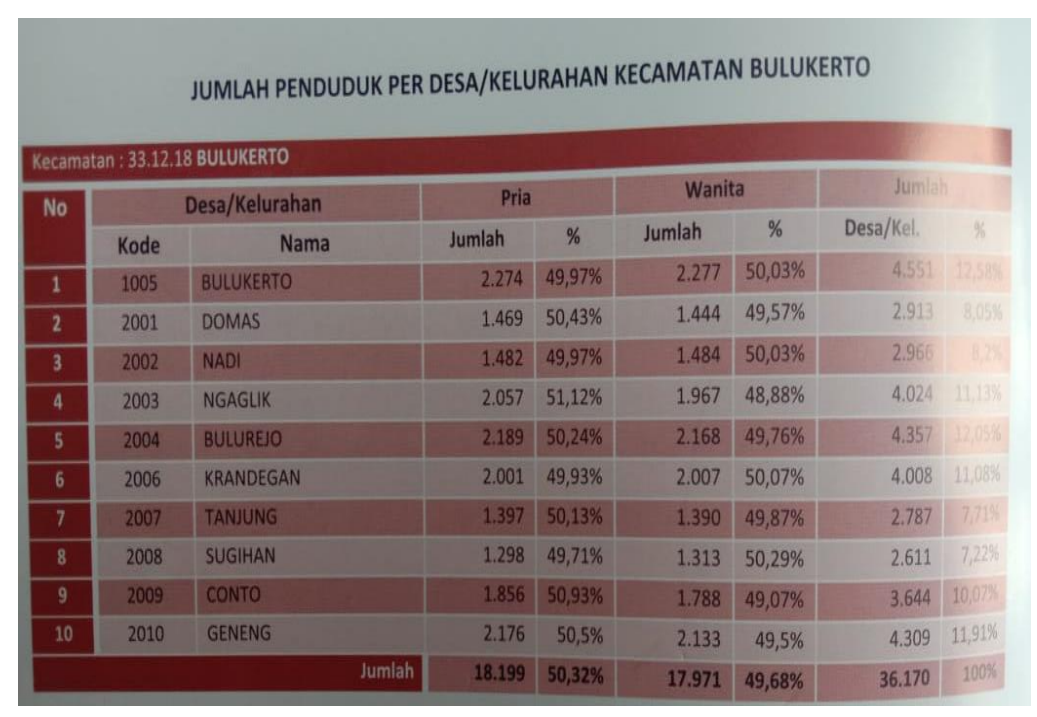

15 Delila Nisnoni, "Evaluasi Proses Implementasi Kebijakan Program UHC (Universal Health Coverage) Di Semarang," Journal of Politic and Government Studies (2020).

${ }_{16}$ Muchsin dan Fadilah Putra. 2002. Hukum Kebijakan Publik. Universitas Sunan Giri, Surabaya. Hal. 16. 
Persebaran penduduk di kecamatan Bulukerto terbagi menjadi 10 desa yang dimana tiap desanya memiliki jumlah penduduk yang berbedabeda. Dari riset yang yang dilakukan, peneliti mencoba untuk mengambil sample wawancara dan kuisoner bagi beberapa pengguna BPJS Kesehatan diwilayah kecamatan Bulukerto.

Data kuisoner penelitian ini untuk menjawab rumusan masalah pada penelitian ini diambil 25 sample yang dimana merupakan masyarakat asli kecamatan Bulukerto yang menggunakan BPJS Kesehatan yang dimana kuisonernya tertera dalam lampiran. Pada kuisoner tersebut terdapat pertanyaan tentang apakah masyarakat terbantu dengan adanya program BPJS Kesehatan dan bagaimana tanggapan masyarakat terkait dengan besaran iuran BPJS yang naik pada saat ini. Hasil kuisoner menyimpulkan bahwa dari 28 responden, 26 responden mengatakan terbantu dengan setuju dengan adanya BPJS Kesehatan dan 2 responden mengatakan tidak terbantu dengan adanya BPJS Kesehatan. Dari data ini dapat terlihat bahwa 97\% responden sebenarnya mengapresiasi positif program pemerintah terkait dengan BPJS Kesehatan yang artinya kesejahteran hukum dapat terlihat jelas disini khususnya di wilayah kecamatan Bulukerto dalam konteks kebijakan adanya BPJS Kesehatan. Disisi lain, 2,5\% responden tidak setuju dengan adanya kebijakan terkait adanya BPJS Kesehatan. ${ }^{17}$

Data kuisoner berbanding terbalik di pertanyaan-pertanyaan selanjutnya terkait dengan kenaikan iuran BPJS Kesehatan dan tanggapan masyarakat terkait kenaikan tersebut. Data kuisoner menyebutkan bahwa dari 28 responden yang masuk, 23 responden memiliki respon yang negatif dari adanya kebijakan kenaikan iuran BPJS. Sedangkan 4 orang memiliki respon atau tanggapan yang cenderung netral dengan alasan

\footnotetext{
${ }_{17}$ Hasil Riset Kuisoner Google Form.
} 
sebagian besar tidak tahu karena bukan mereka pribadi yang mengurusi biaya BPJS Kesehatanya, kemudian hanya 1 orang responden yang memiliki asumsi pendapat positif terhadap kenaikan iuran BPJS Kesehatan yang beralasan bahwa kenaikan tersebut dianggap sangat wajar karena nominalnya cukup ideal. Rata-rata orang atau responden yang memiliki respon negatif mengatakan bahwa iuran kenaikan BPJS Kesehatan pada saat ini sangat mahal dan sangat membebani masyarakat pengguna BPJS Kesehatan apalagi ditengah kondisi pandemi covid-19 pada saat ini. Harapan mereka rata-rata adalah kembali menyesuaikan iuran BPJS Kesehatan sesuai dengan situasi dan kondisi pada saat ini agar tidak membebani masyarakat.

Kesimpulan yang dapat diambil dari hasil kuisoner Google Form ini adalah bahwa pada dasar dan hakikatnya, kebijakan terkait BPJS Kesehatan sangatlah membantu masyarakat dan itu sangat jelas membuktikan sebuah kesejahteraan hukum di wilayah kecamatan Bulukerto. Hal itu dibuktikan dengan dari data responden diatas bahwa 97\% responden sebenarnya mengapresiasi positif program pemerintah terkait dengan BPJS Kesehatan. Akan tetapi, kebijakan yang tertuliskan atau isi dari kebijakan BPJS Kesehatan yang menjadi hal yang dipermasalahkan masyarakat khususnya terkait dengan konteks kebijakan atau aturan kenaikan iuran BPJS. Hal ini juga dibuktikan dengan dari 28 responden Google Form, 23 responden mengatakan sangat keberatan dengan kebijakan ini.

Jadi, kesimpulannya sebenarnya kesejahteraan hukum yang diciptakan di BPJS kesahatan jika dilihat dari data Google Form ini sudah terwujud, hanya saja harapan masyarakat perlu pembenahan dan revisi 
kembali terkait dengan kebijakan kenaikan iuran BPJS Kesehatan yang dianggap sangat membebani masyarakat. ${ }^{18}$

Data selanjutnya, peneliti mencoba untuk melakukan wawancara secara langsung kepada beberapa pengguna BPJS Kesehatan di wilayah kecamatan Bulukerto secara langsung dengan pertanyaan-pertanyaan yang intinya tidak jauh berbeda dengan pertanyaan yang ada pada kuisoner Google Form. Apa yang disampaikan responden sudah diterjemahkan oleh peneliti dari bahasa Jawa ke bahasa Indonesia. Adapun beberapa masyarakat yang memberikan tanggapan dan pendapatnya terkait dengan kenaikan BPJS Kesehatan adalah sebagai berikut :

Pertanyaan:

1. Apakah anda terbantu dengan adanya program BPJS?

2. Bagaimana tanggapan anda tentang besaran iuran saat ini?

3. Bagaimana dampak yang timbul setelah kenaikan iuran saat ini?

4. Bagaimana kelangsungan pembayaran iuran dan ketetapan waktu pembayaran iuran anda?

5. Bagaimana keberlanjutan kepesertaan BPJS anda, apakah tetap kelas atau turun kelas ke kelas II/III/PBI (Penerima Bantuan Iuran)? Jika tetap kelas, sebutkan di kelas berapa?

6. Apa harapan anda terkait peraturan/iuran BPJS Kesehatan kedepannya?

BPJS Kesehatan merupakan program yang sangat berpengaruh dalam kehidupan masyarakat khususnya dalam konteks kesehatan di wilayah kecamatan Bulukerto. Data selanjutnya, peneliti mencoba untuk melakukan wawancara kepada beberapa pengguna BPJS Kesehatan di wilayah kecamatan Bulukerto secara langsung dengan pertanyaanpertanyaan yang intinya tidak jauh berbeda dengan pertanyaan yang ada pada kuisoner Google Form, yang dimana disampaikan responden sudah diterjemahkan oleh peneliti dari bahasa Jawa ke bahasa Indonesia. Adapun beberapa masyarakat yang memberikan tanggapan dan

\footnotetext{
18 Hasil Riset Kuisoner Google Form.
} 
pendapatnya terkait dengan kenaikan BPJS Kesehatan dimana yang dipertanyakan adalah terkait dengan apakah masyarakat terbantu dengan adanya program BPJS, kemudian bagaimana tanggapan masyarakat terkait tentang besaran iuran BPJS saat ini, lalu bagaimana dampak yang timbul setelah kenaikan iuran BPJS tersebut, setelah itu terkait dengan bagaimana kelangsungan pembayaran iuran dan ketetapan waktu pembayaran iuran, dan bagaimana keberlanjutan kepesertaan BPJS, apakah tetap kelas atau turun kelas ke kelas II/III/PBI (Penerima Bantuan Iuran) jika tetap kelas ada di kelas berapa, serta terkait Apa harapan masyarakat terkait peraturan/iuran BPJS Kesehatan kedepannya.

Masyarakat yang pertama menjadi responden adalah ibu Sularti. Beliau merupakan ibu rumah tangga yang hasil perekonomiannya bergantung pada penerimaan pensiunan. Beliau menjelaskan bahwa "ya terbantu. Soalnya kalau pakai itu sudah tidak bayar lagi. Bagi saya tidak masalah, karena biayanya masih ditanggung pemerintah, tetapi kalau masyarakat yang lain mungkin keberatan. Kalau saya pribadi tidak merasakan dampak apapun. Untuk membayarnya tepat waktu, kan kepotong belanja pensiun saya. Masih tetap kelas II. Harapan saya semoga masyarakat Indonesia tetap terbantu dengan BPJS, dan iuran bisa diturunkan." ${ }^{19}$ Dari hasil wawancara ini dapat disimpulkan bahwa masyarakat menganggapi positif kebijakan pemerintah terkait dengan kenaikan BPJS Kesehatan walaupun disisi lain tetap berharap agar iuran BPJS bisa diturunkan. Hal yang sama dan senada juga disampaikan oleh bapak Soetar, yang juga seorang penerima pensiunan. Beliau mengatakan bahwa "terbantu, karena kalau periksa ke Puskesmas tidak membayar lagi. Bagi saya sudah cukup, karena BPJS banyak mengalami kekurangan dana. Bagi saya tidak ada masalah terkait dampaknya. Karena sudah dipotong gaji pensiun, maka pembayarannya tetap. Tetap kelas. Harapan saya berlangsung secara baik. Tidak menolak, tidak meminta gaji terpotong lagi. Bagi

\footnotetext{
19 Sularti. Hasil Wawancara 27 juni 2020.
} 
saya, demi kepentingan nasional tidak masalah, saya ikhlas jatah saya terpotong." 20 Kesimpulan dari apa yang disampaikan beliau hampir sama dengan marasumber sebelumnya, yang menanggapi positif terkait dengan kebijakan kenaikan iuran BPJS Kesehatan dan tetap berharap kepada pemerintah dan masyarakat agar berlangsung secara baik, tidak menolak, tidak meminta gaji terpotong lagi dan demi kepentingan nasional tidak masalah.

Responden lain yang memiliki sikap netral terhadap kebijakan kenaikan iuran BPJS Kesehatan. Hal itu disampaikan oleh ibu Purwanti yang merupakan seorang pedagang yang berusia 50 tahun. Beliau berpendapat bahwa "iya terbantu, karena motivasi saya mendaftarkan diri adalah membantu orang yang sakit, untuk kepentingan semua ya tidak apa apa, yang terpenting iuran masih terjangkau dan sesuai dengan pendapatan saya. Dampaknya adalah saya harus mengluarkan uang lebih, padahal pemasukan sama. Karena saya hanya pedagang, jadi kadang tidak tepat waktu. Tetap kelas. Semoga menjadi lebih baik, dan tepat sasaran. Artinya memang dananya digunakan untuk masyarakat bersama, semoga pejabat di BPJS tidak ada yang korupsi."21 Dari wawancara ini dapat dilihat dan dianalisa bahwa setiap kebijakan itu pasti ada dampak positif dan negatifnya, tinggal bagaimana masyarakat menilai dari sudut pandang yang berbeda beda agar tercipta pemahaman yang jelas dan memiliki harapan cukup besar kepada pemerintah agar tidak menyalahgunakan jabatannya,seperti korupsi dan sebagainya.

Berbanding terbalik dengan 3 responden selanjutnya, bapak Sukamto yang seorang petani berusia 56 tahun berpendapat bahwa "ya mbak saya terbantu, yang bayar anak saya. Ya memberatkan mbak, wong saya cuma petani, uang hanya mengandalkan dari anak saya dan hasil panen 3 bulan

\footnotetext{
20 Soetar, Hasil Wawancara 27 juni 2020.

21 Purwanti, Hasil Wawancara 27 Juli 2020.
} 
sekali. Ya berarti anak saya harus mengeluarkan uang lebih, yang seharusnya sudah cukup jadi kurang. Ya kadang sampai kedenda mbak. Masih tetap, selama kami masih mampu InshaAllah tetap lanjut di kelas III. Semoga iurannya bisa turun seperti semula agar kita semua bisa sejahtera."22 Dari yang disampaikan bapak Sukamto dapat dilihat bahwa kemanfaatan hukum tidak terlihat disini dan bahkan cenderung dapat menyusahkan dan menjadikan masyarakat tidak sejahtera serta terbebani. Harapannya sebenarnya hampir sama dengan beberapa narasumber sebelumnya, hanya saja apa yang disampaikan narasumber ini cenderung memperlihatkan betapa terbebaninya masyarkat terhadap kebijakan yang dikeluarkan oleh pemerintah terkait dengan kenaikan iuran BPJS Kesehatan.

Senada dengan yang disampaikan bapak Sukamto, responden ke 5 ini juga beranggapan hampir sama. Beliau adalah ibu Sukiyati, yang merupakan seorang petani berusia 70 tahun. Beliau berpendapat bahwa. "saya sangat terbantu, karena anak saya sakit berat di Rumah Sakit rujukan dan sangat terbantu oleh BPJS ini. Bagi saya saat ini saya dan suami saya masih mampu membayar, tetapi kalau naik lagi, ya saya keberatan. Awalnya saya terkejut karena naiknya 2 kali lipat dari iuran sebelumnya. Tidak selalu tepat waktu, tapi paling cuma mundur 1 sampai 2 hari saja, karena rumah saya dekat dengan BRI-Link yang bisa untuk membayar tagihan BPJS. Tetap kelas, karena kalaupun turun kelas kasihan anak saya jika dirawat di Rumah Sakit fasilitasnya pasti akan berkurang, walaupun saya hanya petani. Semoga bisa terjangkau dan pelayanan di Rumah Sakit tidak dibeda-bedakan dengan pasien mandiri, dan pasien BPJS tidak di pandang sebelah mata, padahal kami tiap bulan juga rutin membayar iuran."23 Dari yang dituturkan oleh beliau, dapat dianalisa bahwa kebijakan terkait kenaikan iuran BPJS Kesehatan sangat membebani dan merugikan masyarakat sehingga perlu adanya

\footnotetext{
22 Sukamto, Hasil Wawancara 27 Juni 2020.

23 Sukiyati, Hasil Wawancara 27 Juni 2020.
} 
pembenahan terkait kebijakan ini. Harapan beliau lebih cenderung kepada dampak terkait pelayanan publik khususnya Rumah Sakit agar tidak membeda-bedakan pasien antara satu sama lain, memperoleh pelayanan kesehatan yang terbaik dari pihak rumah sakit.

Hasil riset wawancara diatas dapat disimpulkan bahwa dari 5 responden yang dimintai pendapat atau argumentasi terkait kenaikan iuran BPJS Kesehatan terdapat sedikit perbedaan dengan analisa hasil riset sebelumnya yaitu dari responden Google Form. Dari hasil wawancara, dari total 5 responden yang diwawancarai terdapat 2 orang yang berpendapat positif terkait kenaikan BPJS ini yang artinya mendukung program pemerintah tersebut, kemudian 2 orang selanjutnya menganggap bahwa kenaikan iuran BPJS ini memiliki dampak negatif bagi mereka atau dengan kata lain tidak mendukung program pemerintah terkait kenaikan iuran BPJS, lalu 1 orang terakhir berasumsi dan berpendapat cenderung untuk netral. Dari hasil wawancara disebutkan bahwa, alasan 2 orang pertama yang mendukung program kenaikan BPJS Kesehatan adalah mereka menganggap bahwa biaya BPJS masih ditanggung oleh pemerintah dan menganggap kenaikan ini adalah wajar serta alasan lainnya menganggap bahwa BPJS Kesehatan sudah sangat membantu mereka selama ini. Kemudian 2 orang yang memiliki tanggapan negatif atau tidak mendukung beralasan bahwa kenaikan iuran BPJS Kesehatan sangat berpengaruh bagi kehidupan ekonomi mereka karena ada yang hanya memiliki pekerjan seperti petani dan mereka berharap agar tidak terjadi kenaikan lagi. Lalu 1 orang terakhir berasumsi atau berpendapat netral dengan alasan ini untuk kepentingan semua orang walaupun sebenarnya agak keberatan dengan kenaikan iuran BPJS Kesehatan, jadi argumennya cenderung lebih mengutamakan kepentingan orang banyak dibandingkan kepentingan pribadi dan inilah yang disebut netralitas argumen terhadap kenaikan iuran BPJS Kesehatan. 
Kesimpulannya, dari hasil wawancara terhadap 5 responden yang memiliki kartu BPJS Kesehatan 40\% responden mendukung program pemerintah terkait iuran BPJS Kesehatan, kemudian 40\% responden tidak mendukung adanya program kenaikan BPJS Kesehatan, dan 20\% responden berpendapat netral terkait dengan kenaikan iuran BPJS Kesehatan. Jika kita kaitkan dengan kesejahteraan hukum, maka dari hasil wawancara menyimpulkan bahwa masih terjadi problematika terkait kebijakan yang dibuat pemerintah, artinya ada yang pro dan ada yang kontra dan juga ada yang netral. Hal ini diharapkan agar kebijakan yang mendapat pendapat pro atau positif tetap dipertahankan, kemudian kebijakan yang mendapat pendapat negatif atau kontra dapat direvisi atau diperbaiki lagi, dan kebijakan yang mendapat pendapat netral dapat di revisi ulang agar dapat meyakinkan masyarakat karena kembali ke tujuan dari adanya kebijakan adalah untuk kesejahteraan hukum dan masyarakat itu sendiri.

Observasi di lapangan yang peneliti amati, kebijakan ini batal demi hukum, karena tidak sesuai dengan apa tujuan hukum itu sendiri. Adanya kenaikan iuran terhadap BPJS Kesehatan ternyata memiliki pengaruh yang cukup besar terhadap kesejahteraan masyarakat sehingga masyarakat sekarang cenderung lebih kesusahan untuk membayaranya karena kenaikannya pun terkadang tidak sesuai dengan fasilitas yang diberikan dilapangan. Riset yang dilakukan di kecamatan Bulukerto ini menunjukkan bahwa adanya kenaikan iuran BPJS Kesehatan, ternyata memiliki pengaruh dan dampak yang cukup besar terhadap kesejahteraan masyarakat maupun kestabilan hukum. Kesehatan merupakan faktor yang menunjang terpenuhinya hukum nasional. Secara sosial, hukum nasional menciptakan kesejahteraan bagi masyarakat Indonesia. Kesejahteraan itu sendiri dapat diartikan sebagai kemakmuran, keadaan sehat serta keadaan damai. Indonesia terdapat suatu penyelenggara 
Sistem Jaminan Sosial seperti yang terdapat dalam UUD 1945 pasal $28 \mathrm{H}$ yang menyatakan bahwa setiap warga Indonesia berhak mendapatkan hidup sejahtera lahir dan batin, memiliki tempat tinggal dan memperoleh lingkungan hidup yang baik, berhak mendapatkan pelayanan kesehatan dan berhak atas jaminan sosial.

\section{Analisa Dampak, Kepersetaan, dan Harapan Masyarakat terkait}

\section{Kenaikan Iuran BPJS Kesehatan di Wilayah Kecamatan Bulukerto}

Kebijakan adalah sebuah sarana untuk mewujudkan dan menata sesuatu hal agar tercipta kesejahteraan bagi banyak orang. Sudah seharusnya jika sebuah kebijakan ataun peraturan hukum dapat menciptakan kemakmuran dan kesejahteraan bagi masyarakatnya. Dalam penelitian ini, kebijakan yang dianalisa adalah terkait dengan kenaikan iuran BPJS Kesehatan dan bagaimana setelah ada kebijakan ini dampak, kepersetaan, dan harapan masyarakat setelah diberlakukannya kebijakan ini khususnya diwilayah kecamatan Bulukerto.

Peneliti dalam penelitian ini sudah melakukan riset secara kuisoner Google Form, maupun secara langsung (wawancara) dimana hasilnya yaitu dampak dari adanya kebijakan kenaikan iuran BPJS Kesehatan ini, sebagian besar mengatakan bahwa kenaikan iuran BPJS Kesehatan berdampak pada sektor perekonomian masyarakat apalagi ditengah kondisi pandemi covid-19 seperti sekarang ini. Walaupun juga ada beberapa yang mengatakan bahwa kebijakan ini juga tidak terlalu berdampak bagi mereka. Kemudian terkait kepersertaan mereka di BPJS Kesehatan, banyak yang mengeluhkan dan berencana untuk turun kelas agar dapat membayar iuran BPJS Kesehatan, walaupun ada juga yang tetap pada kelasnya. Lalu pendapat sekaligus masyarakat Bulukerto terkait dengan kebijakan kenaikan iuran BPJS Kesehatan adalah :

1. Kebijakan BPJS Kesehatan sebenarnya kebijakan yang sangat membantu masyarakat khususunya di bidang kesehatan. 
2. Kebijakan BPJS Kesehatan sebenarnya sudah bisa menciptakan kesejahteraan hukum maupun kesejahteraan masyarakat.

3. Titik permasalahan, sebenarnya ada pada kebijakan pemerintah yang menaikkan iuran BPJS Kesehatan dimana hal ini menyebabkan masyarakat menjadi resah karena harus membayar lebih mahal apalagi ditengah masa pandemi covid-19 saat ini.

4. Harapan masyarakaat sebagian besar adalah pemerintah segera merevisi peraturan iuran BPJS Kesehatan agar tidak membebani masyarakat tanpa mengubah tujuan utama dibuatnya BPJS Kesehatan.

\section{KESIMPULAN}

Data hasil kuisoner Google Form, menunjukkan bahwa pada hakikatnya, kebijakan terkait BPJS Kesehatan sangatlah membantu masyarakat dan kesejahteraan hukum di wilayah kecamatan Bulukerto. Hal itu dibuktikan dengan data responden sebesar 97\% mengapresiasi positif program pemerintah terkait dengan BPJS Kesehatan. Akan tetapi, kebijakan yang tertuliskan atau isi dari kebijakan BPJS Kesehatan yang dipermasalahkan masyarakat khususnya terkait dengan konteks kebijakan atau aturan kenaikan iuran BPJS Kesehatan. Selanjutnya dibuktikan dengan 25 responden Google Form, 23 responden mengatakan sangat keberatan dengan kebijakan ini. Jadi, kesimpulannya kesejahteraan hukum yang diciptakan di BPJS Kesehatan jika dilihat dari data Google Form ini sudah terwujud, hanya saja harapan masyarakat perlu pembenahan dan revisi kembali terkait dengan kebijakan kenaikan iuran BPJS Kesehatan yang dianggap sangat membebani masyarakat. Hasil wawancara terhadap 5 responden yang memiliki kartu BPJS Kesehatan $40 \%$ responden mendukung program pemerintah terkait iuran BPJS Kesehatan, kemudian 40\% responden tidak mendukung adanya program kenaikan BPJS Kesehatan, dan 20\% responden berpendapat netral terkait 
dengan kenaikan iuran BPJS Kesehatan. Jika kita kaitkan dengan kesejahteraan hukum, maka dari hasil wawancara menyimpulkan bahwa masih terjadi problematika terkait kebijakan yang dibuat pemerintah, artinya ada yang pro dan ada yang kontra dan juga ada yang netral. Hal ini diharapkan agar kebijakan yang mendapat pendapat pro atau positif tetap dipertahankan, kemudian kebijakan yang mendapat pendapat negatif atau kontra dapat direvisi atau diperbaiki lagi, dan kebijakan yang mendapat pendapat netral dapat di revisi ulang agar dapat meyakinkan masyarakat karena kembali ke tujuan dari adanya kebijakan adalah untuk kesejahteraan hukum dan masyarakat itu sendiri.

Dampak dari adanya kebijakan kenaikan iuran BPJS Kesehatan ini, sebagian besar mengatakan bahwa kenaikan iuran BPJS Kesehatan berdampak pada sektor perekonomian masyarakat apalagi ditengah kondisi pandemi covid-19 seperti sekarang ini. Walaupun juga ada beberapa yang mengatakan bahwa kebijakan ini juga tidak terlalu berdampak bagi mereka. Kemudian terkait kepersertaan mereka di BPJS Kesehatan, banyak yang mengeluhkan dan berencana untuk turun kelas agar dapat membayar iuran BPJS Kesehatan tanpa menunggak dan terdenda, walaupun ada juga yang tetap pada kelasnya.

\section{DAFTAR PUSTAKA}

B. Murti, 2000, Dasar Dasar Asuransi Kesehatan, Penerbit Kansius, Yogyakarta Badan Pusat Statistik Kabupaten Wonogiri Tahun 2017.

Data Kementrian Kesehatan Tahun 2013

Dewi Indriyanti Alexandra, 2008, Etika dan Hukum Kesehatan, Pustaka Book Publisher, Yogyakarta.

Hasil Riset Kuisoner Google Form

Muchsin dan Putra Fadilah, 2002, Hukum Kebijakan Publik, Universitas Sunan Giri, Surabaya. 
Indrianingrum, Irawati, and Indah Puspitasari. “Evaluasi Proses Sistem Rujukan Badan Penyelenggara Jaminan Kesehatan Sosial (BPJS) Kesehatan Di Fasilitas Kesehatan Tingkat Pertama (FKTP) Kabupaten Jepara." Jurnal Ilmu Keperawatan dan Kebidanan (2021).

Mundiharno. “Peta Jalan Menuju Universal Coverage Jaminan Kesehatan (Road Map to a Universal Health Coverage)." Jurnal Legislasi Indonesia (2012).

Nisnoni, Delila. “Evaluasi Proses Implementasi Kebijakan Program UHC (Universal Health Coverage) Di Semarang." Journal of Politic and Government Studies (2020).

Rarasati, Desi Hanggono. "Dampak Kenaikan Tarif Bpjs Kesehatan Terhadap Pelayanan Kesehatan Di Kota Malang." Jurnal Politik Muda (2017).

Subari, Eti Dewi Mutiara, Henni Djuhaeni, and Guswan Wiwaha. “Analisis Faktor-Faktor Yang Memengaruhi Intensi Menjadi Peserta Mandiri Jaminan Kesehatan Pada Masyarakat Kota Cirebon." Universitas Padjadjaran (2014).

Mutiara, E.D, Djuhaeni, H; Wiwaha G, 2014, Analisis Faktor Yang Memengaruhi Intensi Masyarakat Menjadi Peserta Mandiri Jaminan Kesehatan Pada Masyarakat Kota Cirebon, Jurnal Fakultas Kesehatan Masyarakat Universitas Padjajaran, Bandung.

http://www.kemkes.go.id/resources/download/jkn/himpunan-

peraturan-jaminan-kesehatan.pdf, diakses pada 6 Juli 2020.

https://id.wikipedia.org/wiki/Bulukerto, Wonogiri, diakses pada 22 Juli 2020.

Undang -Undang Dasar Negara Republik Indonesia Tahun 1945 Pasal 28 $\mathrm{H}$ 
Undang-Undang Nomor 40 Tahun 2004 Tentang Sistem Jaminan Sosial Nasional.

Undang-Undang Nomor 24 tahun 2011 Tentang Badan Penyelenggara Jaminan Sosial

Peraturan Presiden Nomor 64 Tahun 2020 Tentang Perubahan Kedua Atas Peraturan Presiden Nomor 82 Tahun 2018 Tentang Jaminan Kesehatan.

Purwanti, Hasil Wawancara 27 Juli 2020

Soetar, Hasil Wawancara 27 juni 2020.

Sukamto, Hasil Wawancara 27 Juni 2020.

Sukiyati, Hasil Wawancara 27 Juni 2020

Sularti. Hasil Wawancara 27 Juni 2020 